\title{
Investor Behavioral Finance: Examining Its Applicability on Egyptian Investors
}

\author{
Sharif M. Abu Karsh \\ Faculty of Administrative and Financial Sciences, Arab American University, Jenin, Palestine \\ Email: sharif.abukarsh@aaup.edu
}

How to cite this paper: Abu Karsh, S.M. (2018) Investor Behavioral Finance: Examining Its Applicability on Egyptian Investors. American Journal of Industrial and Business Management, 8, 2158-2167. https://doi.org/10.4236/ajibm.2018.811143

Received: September 3, 2018

Accepted: November 11, 2018

Published: November 14, 2018

Copyright $\odot 2018$ by author and Scientific Research Publishing Inc. This work is licensed under the Creative Commons Attribution International License (CC BY 4.0).

http://creativecommons.org/licenses/by/4.0/

(c) (i) Open Access

\begin{abstract}
Behavioral finance is a novel approach in the financial markets domain. It originates due to an urgent need to overcome and deal with the outstanding issues that traditional investors face in today's modern finance system. Thus, it is said that certain investors who do not have perfectly sensible elucidation regarding some financial situations and issues can recognize these issues better by means of certain financial models. Likewise, in a number of behavioral finance models, investors are known to be unable to bring an up-to-date of their beliefs in the correct manner. However, other models show that investors adopt questionable choices in some cases. Thus, this paper introduces the behavioral finance, describes the background and the aims and objectives of the study, and it introduces the standards of the behavioral finance.
\end{abstract}

\section{Keywords}

Financial Theory, Egyptian investors, Stock Analysis, Anchoring Theory, Loss Aversion

\section{Introduction}

The behavioral finance takes its fundamental principles from the economic theory. Thus, it's worth mentioning that Adam Smith declares that "There is insight to the human psychology which is further developed today into behavioral finance". Relatively, there is likeness between both behavioral finance and behavioral economics. This resemblance returns to the strategy that they both apply scientific research on human behavior, social perception, and emotional biases as well. This adoption comes to create creative environment that helps the related parties to be able to make decisions. It also explains the way these decisions and other factors influence market prices and returns and the resources distribution as well. Hence, the aspects of this issue mainly refer to the rationality or de- 
ficiency of economic factors. The nature of behavioral models normally has integrated perceptions from psychology with the neoclassical style of economic theory. Recently, more efforts are concentrated on examining the theoretical finance in relation to the efficient market hypothesis and the increasing domain of the behavioral finance. Thus, the efficient market hypothesis since its progress is considered as a key theory that is widely employed to help in understanding the behavior of various asset markets. However, things have changed in 1970 till 1980. At this period, a large number of studies indicated differences from what is standard when comparing with this theory. In 1990, for instance, the focus mainly was given to the academic discussion; apart from the analysis of these irregularities. In fact, there was an urgent need to explore the efficient market hypothesis through launching in depth studies on human behavior that affects the financial markets. This adoption really leads to provide more focuses to the behavioral finance which is a novel domain to the finance that applies principles of psychology, sociology and other social sciences.

\section{Study Model and Objectives}

\subsection{Study Model}

The model of this study represents the relationship between the dependent and independent variables where the Investor Behavioral Finance is the independent variable and the Modern Financial Theories are the dependent variables. Presented below (Figure 1) the Model of study based on previous studies that implemented internationally.

\subsection{Objectives of the Study}

To test the applicability of behavioral finance theories on Egyptian Investors.

\section{Sub-Objectives}

1) To study the concept of behavioral finance and various theories associated with it.

2) To prove the loss averse nature of investors.

\section{Research Methodology}

\subsection{Research Design}

To check the applicability of Behavioral finance, it is essential to conduct a sample survey among the investors. This is to know the investing behavior of the

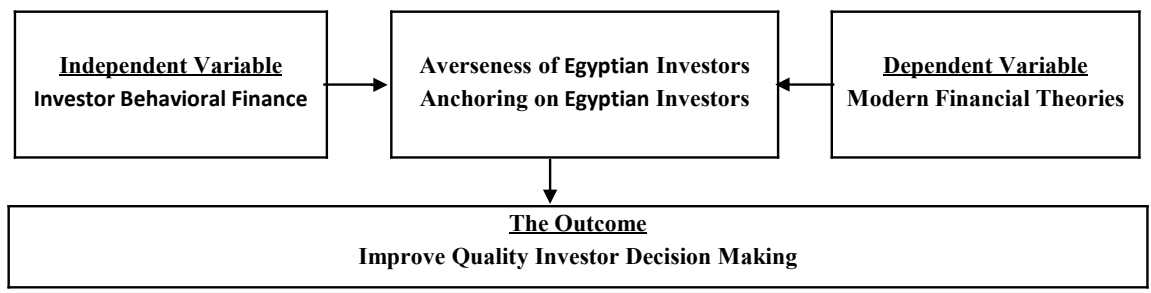

Figure 1. The model of the study-researcher constructed. 
investors. Some brokers and financial institutions are also included with the general investors. A questionnaire has been designed to get information.

\subsection{Research Type}

Descriptive research -in the form of collection of secondary data.

\subsection{Hypothesis}

1) For checking the loss averseness of Egyptian Investors, the hypothesis to be tested is:

"There is no difference in investors' behavior when a stock is losing in the market and when it is gaining in the market."

2) For checking the validity of Anchoring on Egyptian Investors, the hypothesis to be tested is: "There is no difference in investors' perception when the index of a stock market has consequently increased or decreased for three days in a row."

\subsection{Sample Design and Size}

The population from which sample is drawn comes from Egypt. The sample size for the consumer survey is 135 and they are drawn randomly.

\subsection{Hypothesis Testing}

Hypothesis is tested by using Chi-square Analysis, which involves following steps:

1) Calculate the expected frequency of all the given cells, which is worked out as:

Expected Frequency of any cell $=\frac{(\text { Row total of the cell }) \times(\text { Column total of the cell })}{(\text { Grand Total })}$

2) Obtain the difference between observed and expected frequency and find out the difference between such differences i.e., calculate $\left(O_{i j}-E_{i j}\right)^{2}$.

3) Divide the quantity $\left(O_{i j}-E_{i j}\right)^{2}$ by the corresponding expected frequency to get $\left(O_{i j}-E_{i j}\right)^{2} / E_{i j}$ for all the cell frequencies.

4) Find the summation of $\left(O_{i j}-E_{i j}\right)^{2} / E_{i j}$ values. This is the required Chi-Square value $(x 2)$.

$$
x 2=\frac{\sum\left(O_{i j}-E_{i j}\right)^{2}}{E_{i j}}
$$

5) The computed value is then compared to a tabular chi-square value.

If the compared chi-square value is great then the tabular chi-square value at predetermined level of significance, the hypothesis is rejected, otherwise the hypothesis is accepted.

\section{Literature Review}

The Egyptian exchange is one of the oldest stock exchanges in the Middle East. It 
was established in 1883 in Alexandria. Later, in 1903 the Cairo Stock Exchange was established after twenty years from the establishment of Alexandria Stock Exchange. Thus, Alexandria becomes distinguished with one of the oldest markets in the world in the 1800s. Historically, in 1885, Egypt systematized its local trade. Since then the stock exchange has been emerging and developing. The following are the most significant dates that illustrate chronologically important events regarding the stock exchange in Egypt:

1909-Issuance of the first general regulations for the stock exchanges.

1947-Commencement of the over the counter (OTC) market in Egypt.

1980-Establishment of the Capital Market Authority (CMA).

1994-Shift from an outcry system to an automated order-driven system issuing a law to establish Miser for Cleaning, Settlement and Depository Company.

1996-Unifying the trading between Alexandria Stock Exchange and Cairo Stock Exchange.

1997-Egypt was added to the International Finance Corporation Global and Investable indices.

1998-Launching case 30 which became known later as EGX30 with a base value of 1000 Egyptian pounds.

2000-Establishment of Settlement Guarantee Fund to ensure timely settlement of transactions.

2001-Egypt was added on the Morgan Stanley Capital International (MSCI) Emerging.

Markets Free Index (EMF), EMEA and All Country World Index.

2002-EGX started its new price ceiling system that removed 5\% ceiling in daily prices.

With regard to the most active stocks based on fulfilling specific criteria.

2005-same day trading started.

2007-EGX launched NILEX, the first Mid and Small Cap market in the MENA region.

2009-EGX launched EGX100 Price Index and EGX70 Price Index.

2011-EGX launched EGX 20 Index.

2014-EGX launched NILEX First Index.

The study of (Beugelsdijk and Frijns, 2010) [1] comes to examine foreign bias. Hence, foreign bias in international asset allocation is examined by using country-level data. This is due to underlie individual fund level data of mutual fund holdings of 26 countries that are considered as the most developed countries in the investment field. These 26 countries are shown in a sample that consists of 48 countries. The other countries are considered as developing markets. These findings were discussed and explored in 1999-2000. The deviations from the optimal portfolio as described by asset pricing theory were calculated in order to measure the foreign bias and to measure the uncertainty avoidance (UAV) and individualism (IND) as well. They also employed Hofstede's scores in order to measure cultural variance. The findings state that "societies that are more uncertainty avoidant invest less in foreign equity and societies that are more indi- 
vidualistic invest more in foreign equity". They then clarify that when there is an increasing cultural distant between two countries, there will be less investment between them. This also will affect the way they decide their investment destination.

Relatively, the study of (Konukoglu, 2010) [2] in Turkey, demonstrates that from January 1997 to June 2008, foreigners prefer their country as a better place to trade and own shares in the stock market than foreign markets. For them, in spite of this finding, the diversification is considered to be highly profitable. The study explains this finding due to reasons that in some aspects refer to their lack of knowledge of these markets. As a result, this rather traps them to sell at lower prices. This also forced them to move towards finding larger and more liquid stocks that are enriched with less foreign exchange risk and more levels of financial data as well. What's more, information asymmetry is considered as another conceivable clarification regarding the trading behavior in the market. This is defined as the alterations amongst investor's collection and processing of information on international investments. Hence, many studies argued that investors with greater information compared to other traders can better get advantage of this data in their trading and then leads to gain better profits.

In the context of international equity investments, previous studies from various markets show that domestic investors are better informed than their foreign counterparts as, on average, local investors are better informed on the payoff structure of local securities than foreign investors.

Another study by (Jay R. Ritter, 2003) [3] introduces brief summary on the behavioral finance. The study says that behavioral finance includes studies that exclude the traditional norms of anticipated value extension with rational investors in the developed markets. However, the main two basis of behavioral finance mentioned in the article are cognitive psychology that clarify how people think; while the other is the limits to arbitrage that clarify when markets will be inefficient.

Relatively, the study of (Meir Statman, 1999) [4] emphasis on the fact that market efficiency arises from behavioral finance, standard finance, in addition to the value of investment professionals. Remarkably, the study defines the concept market efficiency in two different ways. Firstly, it defines market efficiency as the ability of investors of dealing with the market systematically. The other definition states that security prices are rational which reflects only applied features such as risk, not value-expressive characteristics and sentiment. Hence, behavioral finance demonstrates that value-expressive features affect equally investor choices and asset prices as well.

Another study by (Richard Fairchild, 2004) [5] explains the relation between both behavioral finance and capital budgeting models and clarifies their concept. What's more, the study emphasizes on the effects of managerial unreasonableness in relation to capital budgeting. Thus, the study examines three behavioral influences as following: A. The mutual relation that is distinguished with trust between the investors and the managers. $\mathrm{B}$. The effect of framing behavior in- 
itiates by unreasonable acceptance to a risk that must be rejected. C. The effect of framing behavior accompanied with managerial exceeded assurance which leads to massive levels of effort.

Another authentic reference is (The Wall Street Journal, 2009) [6]. It states that the majority of investors are rational; whereas others are irrational. Hence, behavioral finance helps in telling us when we are thinking rationally; and when we think emotionally. It adds that there is instability of our thinking and mood which affects our behavior from time to another. For instance, Albert Phung, Invest opedia clarifies that" According to conventional financial theory, the world and its participants are, for the most part, rational "wealth maximizes". Doubtlessly, it becomes a fact to say that behavioral finance is a novel domain that combines both conventional economics and finance with behavioral and cognitive psychological principle in order to deliver reasons that explains why people make financial decisions irrationally.

\section{Results and Discussion}

\subsection{Loss Averseness of Egyptian Investors}

It is worth mentioning that sensitivity to losses is less than gains loss aversion. This fact is justified due to the tendency of investors to stop manufacturing stocks when loss occurred and selling attractive stocks early. There is unevenness regarding the values that investors put on gains and losses. A questionnaire shows that 86 investors prefer to hold stocks if losses occurred. In contrast, it shows that 49 will sell theirs. However, 90 chose to sell the stocks when if the market is prosperous which states that 45 will hold stocks. Chi-Square Analysis illustrates the aforementioned finding in details.

There is no difference in investors' behavior when a stock is losing in the market and when it is gaining in the market. "See Table 1".

The expected frequency of all the given cells is worked out as: "see Table 2" and "see Table 3".

Expected Frequency of a cell $=\frac{(\text { Row total of the cell }) \times(\text { Column total of the cell })}{(\text { Grand Total })}$

$$
\text { Chi-Square value }(x 2)=\frac{\sum\left(O_{i j}-E_{i j}\right)^{2}}{E i_{j}}=24.926
$$

The degree of freedom is $\left\{(\mathrm{r}-1)^{\star}(\mathrm{c}-1)\right\}$, where $\mathrm{r}$ equals to row involved, and $\mathrm{c}$ is the no. of columns, so degree of freedom is $\left\{(2-1)^{\star}(2-1)\right\}$ or 1 . The level of significance chosen is 0.05 . On this basis tabular $x 2$ (Chi-Square) is 3.84 .

Table 1. Observed frequency $\left(O_{i j}\right)$.

\begin{tabular}{cccc}
\hline & Sell Stock Now & Hold Stock for a month & Total \\
\hline Loosing Stock & 49 & 86 & 135 \\
Gaining Stock & 90 & 45 & 135 \\
Total & 139 & 131 & 270 \\
\hline
\end{tabular}


Table 2. Expected frequency $\left(E_{i j}\right)$.

\begin{tabular}{cccc}
\hline & Sell Stock Now & Hold Stock for a month & Total \\
\hline Loosing Stock & 69.50 & 65.50 & 135 \\
Gaining Stock & 69.50 & 65.50 & 135 \\
Total & 139 & 131 & 270 \\
\hline
\end{tabular}

Table 3. Calculation of Chi Square.

\begin{tabular}{cccccc}
\hline Cell $(\mathrm{i}, \mathrm{j})$ & $O_{i j}$ & $E_{i j}$ & $\left(O_{i j}-E_{i j}\right)$ & $\left(O_{i j}-E_{i j}\right)^{2}$ & $\left(O_{i j}-E_{i j}\right)^{2} / E_{i j}$ \\
\hline$(1,1)$ & 49 & 69.50 & -20.50 & 420.25 & 6.047 \\
$(1,2)$ & 86 & 65.50 & 20.50 & 420.25 & 6.416 \\
$(2,1)$ & 90 & 69.50 & 20.50 & 420.25 & 6.047 \\
$(2,2)$ & 45 & 65.50 & -20.50 & 420.25 & 6.416 \\
\hline
\end{tabular}

Since, the computed $x 2$ (Chi-Square) value is 24.926 , the hypothesis is rejected. Thus, there is a difference in investors' behavior when a stock is losing in the market and when it is gaining in the market.

The risk aversion in gains causes investors to sell too quickly into rising stock prices, thereby depressing prices relative to fundamentals. Conversely, risk seeking in losses causes them to hold on too long when prices decline, thereby causing the prices of stocks with negative momentum to overstate fundamental values.

\subsection{Relevance of Anchoring in Respect to Egyptian Investors}

Anchoring is employed to refer to the manner individuals focus on current conduct and pay less attention to longer tendencies. Thus, anchoring is considered to be the greatest remembered price. Therefore, investors lean toward using anchoring so as to put into effect similar stock prices from a day to the other. Likewise, a questionnaire shows that 51 respondents think rationally where they argue that it's difficult to predict the market. However, in an upward, market tendency of three days, for instance, 37 investors assumed that it is possible to find a related tendency, though 47 assumed that it will reverse. In contrast, in a downtrend, there were 51 rational respondents who believe that it's impossible to predict the market. Further, 27 respondents came out with a related trend; whereas 57 thought in reverse trend. Thus, the propensity of prior prices will function as anchors which will clarify the detected propensity of trends in the reversed individual stocks prices.

The validity of Anchoring is checked by the Chi-Square Test.

There is no difference in investors' perception when the index of a stock market has consequently increased or decreased for three days in a row. "See Table 4".

The expected frequency of all the given cells is worked out as: "see Table 5" and "see Table 6". 
Table 4. Observed Frequency $\left(O_{i j}\right)$.

\begin{tabular}{cccc}
\hline Market Trend & Increase $^{*}$ & Decrease $^{*}$ & Total \\
\hline Increase for three days & 37 & 47 & 84 \\
Decrease for three days & 57 & 27 & 84 \\
Total & 94 & 74 & 168 \\
\hline
\end{tabular}

*Indicates the market trend on the fourth consecutive day.

Table 5. Expected frequency $\left(E_{i j}\right)$.

\begin{tabular}{cccc}
\hline & Sell Stock Now & Hold Stock for a month & Total \\
\hline Loosing Stock & 47 & 37 & 84 \\
Gaining Stock & 47 & 37 & 84 \\
Total & 94 & 74 & 168 \\
\hline
\end{tabular}

Table 6. Calculation of chi-square.

\begin{tabular}{cccccc}
\hline Cell $(\mathrm{i}, \mathrm{j})$ & $O_{i j}$ & $E_{i j}$ & $\left(O_{i j}-E_{i j}\right)$ & $\left(O_{i j}-E_{i j}\right)^{2}$ & $\left(O_{i j}-E_{i j}\right)^{2} / E_{i j}$ \\
\hline$(1,1)$ & 37 & 47 & -10 & 100 & 2.128 \\
$(1,2)$ & 47 & 37 & 10 & 100 & 2.703 \\
$(2,1)$ & 57 & 47 & 10 & 100 & 2.128 \\
$(2,2)$ & 27 & 37 & -10 & 100 & 2.703 \\
\hline
\end{tabular}

Expected Frequency of a cell $=\frac{(\text { Row total of the cell }) \times(\text { Column total of the cell })}{(\text { Grand Total })}$

$$
\text { Chi-Square value }(x 2)=\frac{\sum\left(O_{i j}-E_{i j}\right)^{2}}{E_{i j}}=9.662
$$

The degree of freedom is $\left\{(\mathrm{r}-1)^{\star}(\mathrm{c}-1)\right\}$, where $\mathrm{r}$ equals to row involved, and $\mathrm{c}$ is the no. of columns, so degree of freedom is $\left\{(2-1)^{\star}(2-1)\right\}$ or 1 . The level of significance chosen is 0.05 . On this basis tabular $x 2$ (Chi-Square) is 3.84 . Since, the computed $x 2$ (Chi-Square) value is 9.662 , the hypothesis is rejected.

Thus, there is a difference in investors' perception when the index of a stock market has consequently increased or decreased for three days in a row, which shows that the anchoring theory is relevant in case of Indian Investors.

\section{Conclusions and Suggestions}

\subsection{Conclusions}

The following conclusions may be drawn on the basis of study findings:

1) Stable returns are preferred by the majority of investors notwithstanding the fact that they possibly be lower.

2) The data provided from companies, on the first hand, is considered as a very essential item for the majority of respondents in their investment. It is con- 
sidered as a foundation stone for the purpose of analysis fundamentals. On the second hand, the process of making decision of investments requires taking into account the importance of employing forecasts of Historical Performance and Professional due to its importance in this regard.

3) Gamble and hold on are preferred by investors over loosing stock as they expect the prices will get better. Hence, the tendency of investors leans towards being tolerant in accepting risk when threatened with losses.

4) Selling a winning stock early might become the investor's choice which expose that they tend to avoid risk in gains.

5) A large number of respondents adopt rational decision that is to sell a losing stock so as to invest in a gaining one.

6) There are an increasing number of investors who show their tendency towards expecting that at whatever time the Sensex bullish or bearish for three days in a row, market won't indicate a similar trend or alter its trend.

7) In Egypt, investor's behavior shows their tendency towards Loss Averse; in which their losses and gains show differences in their behavioral tendency.

8) Investors in Egypt can make use of the findings that show that anchoring match their finance behavior. A period of three consecutive days of stock market past performance is considered as a trigger that shifts the investors' perception regarding market trend.

\subsection{Recommendations}

The following recommendations are made on the basis of finding of the study to avoid mistakes in financial investments decisions by applying behavioral finance:

1) it's important to understand the marked in different aspects especially its psychological mood as foundation stone afore establishing or thinking of starting any investment. Thus, investors mustn't depend only on fundamental analysis because this may lead to incorrect assumptions.

2) it's important to assure that your source of information is confidential and trusted one. Also, the company's announcements must be adjusted in portfolios.

3) It is highly recommended that losing stocks must be disposed in a case of negative news occurrence.

4) The quality of anchored figure is considered insufficient and it must be examined. Hence, anchoring to an expectation is founded reasonable.

\section{Conflicts of Interest}

The authors declare no conflicts of interest regarding the publication of this paper.

\section{References}

[1] Beugelsdijk, S. and Frijns, B. (2010) A Cultural Explanation of the Foreign Bias in International Asset Allocation. Journal of Banking \& Finance, 34, 2121-2131. https://doi.org/10.1016/j.jbankfin.2010.01.020 
[2] Konukoglu, E. (2010) Uninformed Momentum Traders.

[3] Ritter, J.R. (2003) Behavioral Finance. Pacific-Basin Finance Journal, 11, 429-437. https://doi.org/10.1016/S0927-538X(03)00048-9

[4] Meir, S. (1999) Behavioral Finance: Past Battles and Future Engagements. Financial Analysts Journal, 55, 18-27. https://doi.org/10.2469/faj.v55.n6.2311

[5] Richard, F. (2004) Behavioral Finance in a Principal-Agent of Capital Budgeting. http://www.bath.ac.uk/management/research/papers.htm

[6] Morgan, J.P. (2004) Introduction to Behavioral Finance. http://www.transatlantikinstitut.de/eng/dateien_projekte/behavioral_sciences.html 